\section{The Importance of Positive Word-of-Mouth (PWOM) in Leisure Services Consumption by Third Age Consumers}

\author{
Juan Carlos Eiras Fontenla ${ }^{1}$ \\ ${ }^{1}$ Unicamp, Institute of Economics - Marketing Specialization, Campinas, Brazil \\ Luciana Florêncio de Almeida ${ }^{2}$ \\ ${ }^{2}$ ESPM-SP, Post Graduation in Business Administration, Sao Paulo, Brazil
}

Recebimento:

09/19/2018

Aprovaçáo:

$12 / 12 / 2019$

Editor responsável:

Prof. Dr. Helena Nobre

Avaliado pelo sistema:

Double Blind Review

\begin{abstract}
Purpose - The present study aimed to identify why positive wordof-mouth (PWOM) is important in leisure services consumption by third age consumers.
\end{abstract}

Design/methodology/approach - Using a qualitative and exploratory approach, involving interviews and audio diaries and content analysis to process the data, the study investigated consumers in Brazil aged between 60 and 70 years old.

Findings - The main results indicated that factors generated by PWOM such as safety, engagement, relief, knowledge acquirement, social network, confidence, positive expectations, and enthusiasm appeared to be strong and are fundamental to third age consumers' purchase decision process. A significant nexus was also found between the relevance of PWOM and the fact that it was given by people close to the receiver.

Originality/value - This paper contributes to the prior literature with a better understanding of factors generated by PWOM among third age consumers. Firms and governments can use this to help simplify the choices of elderly consumers and drive their consumer decisions.

Keywords - Word-of-mouth, third age, consumer behavior, service, leisure.

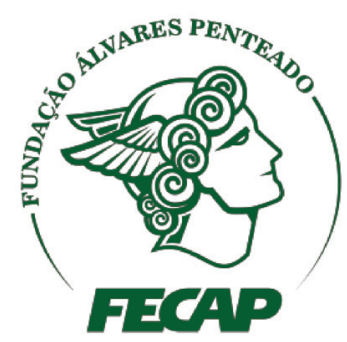

Revista Brasileira de Gestáo de Negócios

DOI: $10.7819 /$ rbgn.v22i3.4073 


\section{Introduction}

The current level of population aging is unprecedented in the history of mankind (United Nations, [UN], 2015). Specifically in Brazil, the population is aging twice as fast as the world average (Instituto Brasileiro de Geografia e Estatística [IBGE], 2016). Factors such as social isolation and the possibility of cognitive decline lead these elderly consumers to adopt conservative purchase behaviors (East, Uncles, \& Lomax, 2014; Lambert-Pandraud, \& Laurent, 2010).

For all consumers, a pre-purchase evaluation is usually necessary due to the perceived risks in consumption situations. However, services are often indivisible and, therefore, prior testing is not possible. Intangibility, heterogeneity, perishability, and indivisibility of services lead to high perceptions of risk (Murray, 1991). Hence, word-of-mouth (WOM) is more important in a service context, since it helps to reduce the risk associated with such situations (Ennew, Banerjee, \& Li, 2000; File, Cermak, \& Prince, 1994; East, Uncles, Romaniuk, \& Riley, 2015). As pointed out by Woodside and Delozier (1976), WOM represents a risk-reducing tool during the purchase evaluation process.

Prior studies on WOM have indicated it as a relevant social phenomenon used to minimize risks associated with consumption (Roselius, 1971; Settle \& Alreck, 1989; Wangenheim \& Bayo'n, 2004; Woodside \& Delozier, 1976). It contributes to both emotional and rational purchasing (Allsop, Bassett, \& Hoskins, 2007; Herr, Kardes, \& Kim, 1991; Kisielius \& Sternthal, 1986; Söderlund \& Rosengren, 2007; Sundaram, Kaushik, \& Webster, 1998), it influences perceptions of service quality (Allsop et al., 2007; Liljander \& Strandvik, 1994; Mazzarol, Sweeney, \& Soutar, 2007; Tax, Chandrashekaran, \& Christiansen 1993), and it reduces risks associated with the purchase of a service (Ennew et al., 2000; File et al., 1994; Murray, 1991).

The majority of WOM studies explore the interpersonal communication structure from the sender's point of view. In the present study, the focus is on the WOM receiver. As pointed out by Martin (2017) and Martin and Lueg (2013), recent research is placing particular emphasis on the receiver's decision making. These studies focusing on the receivers might elucidate how WOM influences them and present propositions for tailoring accurate marketing strategies based around WOM.

The amount of recommendations received by men and women falls substantially after the age of 65. This shortfall in recommendations may be part of the explanation for the conservative decision making by this age group (East et al., 2014). Additionally, personal interaction motivations are relevant in their consumption decisions. This public tends to seek activities that allow for greater coexistence with friends, learning, and self-realization. As a consequence, the third age group mostly consumes services related to leisure, including, for instance, classes (e.g., gym, dance), travel (e.g., agencies, cruises), accommodation (e.g., hotels, resorts), food and drink (e.g., restaurants, bars), music (e.g., shows, concerts), the movie theater, the theater, and others (Hung \& Crompton, 2006; Myers \& Lumbers, 2008).

Despite the other terms found in the literature, such as "older," "senior," and "elderly," this study uses the "third age" label and it focuses on young seniors (Bacha, Strehlau, \& Perez, 2006). For Bacha et al. (2006), due to the third age segment covering a broad age range of approximately 30 years, it is usual to distinguish between two groups: the younger group and the older group. Moschis (1996) argues that chronological definitions need to be put in an appropriate perspective. For instance, scholars or companies focused on nursing homes should concentrate on the upper age group. In the case of companies or studies targeting leisure services, these should focus on a lower age group of elderly people (Moschis, 1996).

Concerning the prior literature focused on the effects of WOM on the third age population, 
a number of contributions have been made by several scholars (Hung \& Crompton, 2006; Myers \& Lumbers, 2008; East et al., 2014). Nevertheless, studies focused on the effect of positive WOM (PWOM) on service purchasing from the perspective of young seniors were not identified in the literature reviewed. In this sense, this paper contributes to the current literature on PWOM by investigating third age consumer behavior related to service purchases.

Although the potential of WOM as a form of promotion is generally accepted (Arndt, 1967; Buttle, 1998; Dye, 2000), it is important to understand that PWOM is not enough to be an effective source of communication. The receiver also needs to react positively to the recommendation. The factors that improve a consumer's chances of acting on PWOM and that change the receiver's perceptions and behaviors in relation to a particular organization still remain less understood (Sweeney, Soutar, \& Mazzarol, 2008). Since WOM is known to convey the idea of enjoyable new experiences when positive and disagreeable ones when negative, WOM receivers can be affected emotionally and rationally (Anderson, 1998).

This study aimed to identify why PWOM is important in leisure services consumption by third age consumers. The secondary objectives of the research are as follows:

- - to investigate the contributions, sensations, and feelings that are generated by PWOM regarding possible risks associated with service purchases, perceptions of service quality, and the decision-making process;

- $\quad$ to explore how PWOM might mitigate third age conservative purchase behavior, such as choice repetition, purchase postponement, and change-over aversion.

Using a qualitative and exploratory approach, this study investigated PWOM receivers in Brazil aged between 60 and 70 years old, regarding their leisure consumption, for example of classes (e.g., gym, dance), travel (e.g., agencies, cruises), accommodation (e.g., hotels, resorts), food and drink (e.g., restaurants, bars), music (e.g., shows, concerts), the movie theater, the theater, and others. Both in-depth interviews and audio diaries were applied to collect the data. The NVIVO software (version 12.4.0) was used for the data interpretation through coding and grouping.

This manuscript is divided into 5 sections, including this introduction, followed by a literature review, the methodological approach, the findings and discussion, and the conclusion.

\section{Literature Review}

\section{I Word-of-mouth}

WOM is defined as an informal conversation among particular parties on the appraisal of goods and services (Anderson, 1998) and has an interactive and swift nature (East, Hammond, \& Lomax, 2008). It is also seen as a highly credible source of information, since the sender is generally independent of the organization providing the service and does not receive direct benefits in defending it (Silverman, 2011). Another relevant point to consider in relation to WOM is its greater influence in a service consumption context, since services are intangible, difficult to evaluate before purchasing, not covered by guarantees, and non-standardized. Thus, services involve higher-risk choices than products (Murray, 1991). Therefore, WOM has greater relevance in services consumption, as it minimizes this risk situation (Ennew et al., 2000; File et al., 1994).

It is widely accepted by researchers and managers that WOM can generate benefits for organizations. It is usually recognized that the receiver considers WOM to be especially relevant and it is subject to less resistance than marketerproduced communications (Allsop, Basset, \& Hoskins, 2007; Söderlund \& Rosengren, 2007; Sweeney, Soutar, \& Mazzarol, 2014; Wien \& Olsen, 2014). Thus, many organizations have 
reduced spending on traditional advertising and reviewed WOM as an alternative marketing communication tool (Sweeney et al., 2008).

The dissemination of WOM has been designated by marketing researchers as being a contagious process, by which receivers capture others' feelings by means of social interaction (Berger, 2014). WOM receivers process the sender's features and the quality of the message content. These components have been shown to individually impact both attitude and WOM acceptance (Mahapatra \& Mishra, 2017). From this perspective, the content of the message is critical, given its potential in making the communication more persuasive.

Figure 1 presents the main components and aspects of WOM.

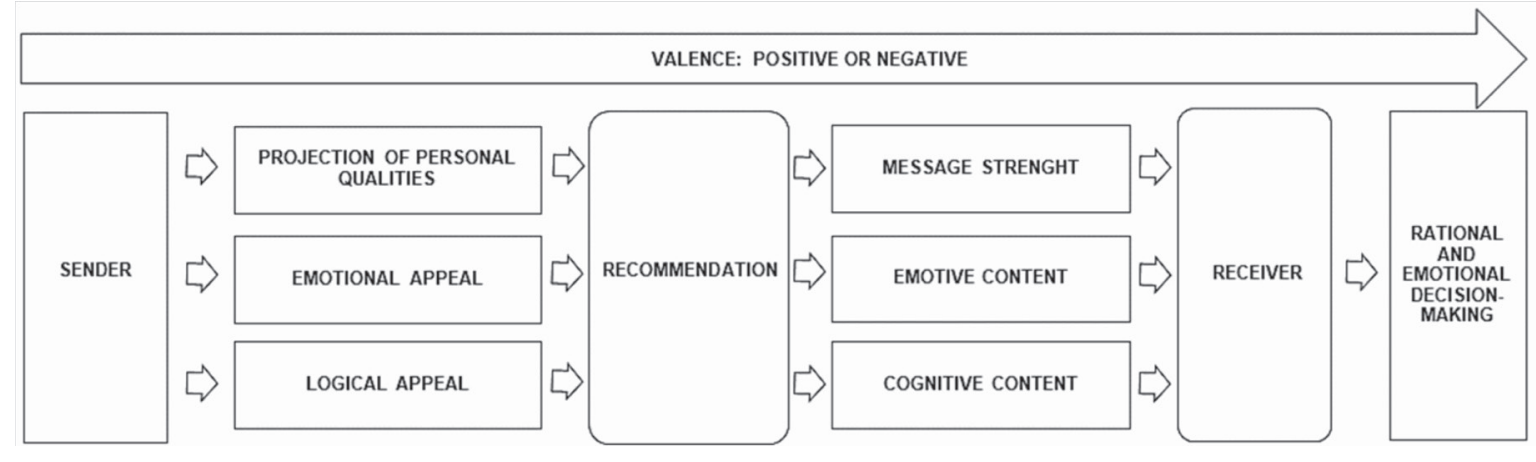

Figure 1. WOM: Components and aspects

WOM can be a result of a range of antecedents, as shown by East et al. (2015). These authors confirmed that a substantial part of WOM related to services is based mainly on dis/satisfaction, meaning that PWOM follows satisfaction with a service and negative WOM (NWOM) is generated by dissatisfaction with a service.

Although earlier studies claim that NWOM would have a greater impact on the receiver (Arndt, 1967), recent research suggests that PWOM has more influence than NWOM on purchase intention. A negative message is less useful than a positive one for many consumer choices (East, Uncles, Romaniuk, \& Lomax, 2016). According to Sweeney et al. (2014), PWOM is more effective overall, is less dependent on situational or conditional factors, and has a greater influence on people's willingness to use a service than NWOM. Even though the valence is crucial, recommendations can be improved by means of the depth, intensity, and liveliness of a message (Mazzarol et al., 2007).
In the emotional field, there is the suggestion that vivid, interesting, provocative, or attention-grabbing information is more accessible in the memory because it weighs heavily on cognitive analysis and has a greater impact on judgments (Herr et al., 1991; Kisielius \& Sternthal, 1986; Mazzarol et al., 2007). This is consistent with the recognition that emotions play an important role in the transmission and reception of WOM (East et al., 2008; Söderlund \& Rosengren, 2007).

On the other hand, WOM also has a rational dimension and significantly influences the perception of a company's reputation (Allsop et al., 2007). Perceptions about the quality of a service can be translated into a rational form of WOM, depending on several motivations or situational or personal characteristics (Mazzarol et al., 2007; Tax, Chandrashekaran, \& Christiansen, 1993).

Sundaram et al. (1998) also advocate for the rational dimension of recommendations, since a series of consumer experiences describe message 
content according to performance, response to problems, and price perceptions.

\subsection{PWOM and consumption risks}

WOM has been recognized as a key reducer of various forms of risk, such as functional, financial, psychological, and social ones (Roselius, 1971; Settle \& Alreck, 1989).

According to Wangenheim and Bayón (2004), in general, these types of risks can be classified into two major groups: functional or financial risk and psychological risk. The first is product-centric and relates to financial performance and loss. Psychological risk is focused on the consumer and results from the interaction with their social environment (Wangenheim \& Bayón, 2004).

It is not surprising that empirical research has found a strong correlation between the two types of perceived risk - functional and financial - since a consumer will almost certainly perceive a financial loss if the product does not meet their needs (Kaplan, Szybillo, \& Jacoby, 1974).

Perceived risk is inherent in many purchasing situations, which explains why consumers seek to make a pre-purchase judgment. However, according to Murray (1991), services are often intangible, difficult to evaluate before purchasing, not covered by guarantees, and nonstandardized. Because of these characteristics, they lead to high perceptions of risk. Consequently, as already noted, WOM is more important in service consumption contexts, since recommendations are one of the most effective sources of information to reduce the risk perceived in service purchases (Murray, 1991).

In this regard, we present the first research proposition:

P1: PWOM acts as a reducer of service risk perception.

\subsection{PWOM and service quality perception}

Since services are difficult to assess, corporate image is an important factor that influences the customer's perception of service quality (Anderssen \& Lindestad, 1998). Corporate image can be described as perceptions of an organization reflected in consumer memory associations (Keller, 1993). A service company's image is expected to function as a filter in the perception of quality, value, and satisfaction, and in simplifying the decision-making process (Anderssen \& Lindestad, 1998).

According to Parasuraman (1987), it is the service-providing process, particularly the provider-customer interactions, that dominates the customer's evaluation. The author highlights the importance of a company culture that values non-routine services, which become necessary when an exception or problem occurs. If the company has the right culture, it can not only solve the problem but also enhance its reputation through invaluable WOM.

Therefore, there is a positive and significant relationship between the customer's perceptions regarding the service quality and their willingness to recommend the company (Parasuraman, Berry, \& Zeithaml, 1991). Boulding, Kalra, Staelin, and Zeithaml (1993) also found a positive correlation between service quality, repurchase intention, and willingness to recommend. According to Hartline and Jones (1996), service quality is a widely recognized antecedent of WOM.

According to Sweeney et al. (2008), the chances of a sender providing recommendations are reinforced by their satisfaction with the service experience. From the receiver's perspective, it is more likely that they will act on a recommendation if they already have a good opinion of the service provider. An organization that invests both in efficient customer service management and effective promotion of its corporate image probably receives greater benefits from WOM, as there is reinforcement of the information provided in the communication process (Sweeney et al., 2008).

WOM can incorporate value by means of the sender-receiver expertise differential, which fosters consumer education about the nature of 
the services being offered (Liljander \& Strandvik, 1995; Sweeney et al., 2014).

From this perspective, the second proposition is presented:

P2: $P W O M$ acts as an attestation of perceived service quality.

\subsection{Third age consumers: WOM, the decision-making process, and conservative purchase behavior}

According to East, Uncles, and Lomax (2014), the time that an elderly person remains as a customer of the same brand is used as a measure of purchase postponement. Permanence with the same brand is longer when fewer recommendations are received. Some seniors experience a degree of social isolation, which affects their decision-making process (East et al., 2014).

In order to explain preferences among third age consumers, it is necessary to study how the decision-making process varies with age. Currently, research on this aspect of the decisionmaking process has focused mainly on variations in the cognitive and affective processes as people age (Cole et al., 2008; Drolet, Lau-Gesk, Williams, \& Jeong, 2010; Lambert-Pandraud, Laurent, \& Lapersonne, 2005; Lambert-Pandraud, \& Laurent, 2010).

The conservatism of senior purchasers could be associated with cognitive decline, which increases cognitive effort in decision making, and pushes the elderly into decision heuristics, such as choice repetition, purchase postponement, and change-over aversion (Lambert-Pandraud et al., 2005; Phillips \& Sternthal, 1977).

East et al. (2014) suggest that social influence can assist consumers in their decisions, driving individual processes and leading to a more careful consideration of options, as well as a shorter purchase postponement. In addition, it can include information about companies, products, and services and, therefore, directly affect decisions. According to Sweeney et al.
(2014), WOM that involves customer education and socialization enhances the influence of the message.

Social influence depends on social contact, which in turn depends on the survival of friends and relatives and adherence to groups related to education, neighborhood, work, friendship, and family. The relationships created in the job environment will cease or substantially reduce with retirement, although they can be compensated for by others (East et al., 2014).

Another possible explanation is socioemotional selectivity. Third age people tend to experience greater activation of their emotive centers, leading to a focus on affective information as they advance in age (East et al., 2014).

Drolet et al. (2010) suggest that the focus on affective information with advancing age is associated with a greater focus on the present and near future. Thus, there is more attention paid to established emotional contacts rather than new information, which results in third age consumers focusing on people they know well. As a consequence, there are fewer social interactions (Carstensen, Isaakowitz, \& Charles, 1999).

Baker, Donthu, and Kumar (2016) offer insights about the influence of interpersonal characteristics on WOM outcomes. Particularly, the researchers suggest that the strength of the social tie relationship tends to influence the WOM receiver's purchase intentions.

Mahapatra and Mishra (2017) suggest that WOM receivers prefer purchase context information from people with whom they are familiarized. Martin and Lueg (2013) indicate that the receiver's perceptions of the sender's trustworthiness and altruism have a strong impact on whether the receiver will use the information provided when determining a course of action. The level to which the receiver trusts a WOM sender has a heavier influence than the sender's expertise or awareness of the product. In addition, the trustworthiness of the WOM sender has a greater impact when the receiver perceives that they have little awareness of the product (Martin \& Lueg, 2013). 
Finally, another mechanism that produces conservative behaviors is change-over aversion (Wallach \& Kogan, 1961). This phenomenon leads the elderly to avoid the choice process, which drives these decision makers toward more familiar options where the risks may be lower (East et al., 2014).

Although the elderly receive fewer recommendations, research by East, Uncles, and Lomax (2014) indicates that third age people respond to recommendations as much as younger people. This responsiveness suggests that marketing communications can be just as successful with both groups.

According to the theories described in this study, the potential reasons that lead elderly consumers to adopt conservative buying behavior were observed. Figure 2 summarizes these factors.

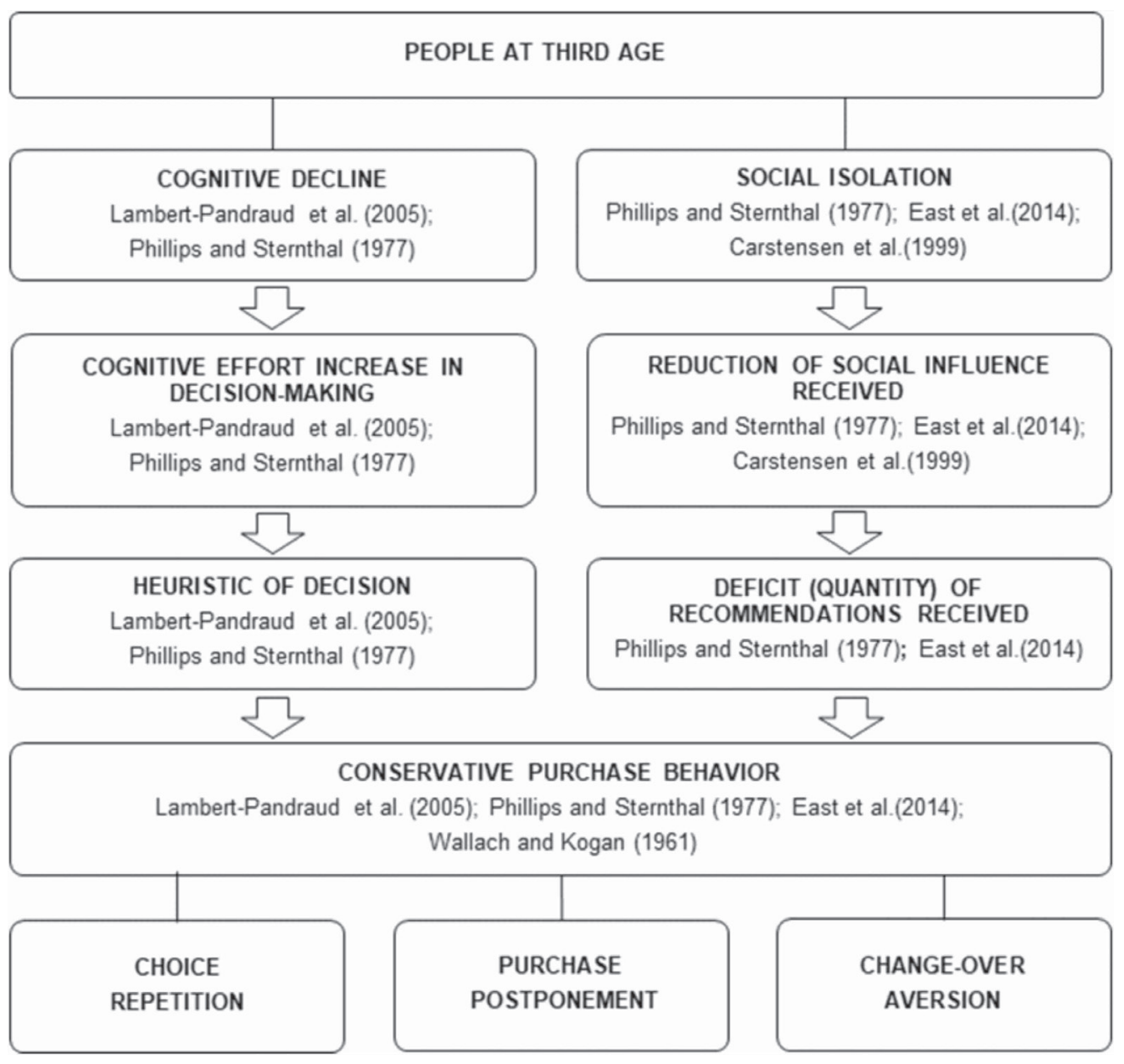

Figure 2. Conservative purchase behavior among the elderly

The literature herein presented supports the third and fourth research propositions:

P3: PWOM acts as an ally in the purchasing decision process and,

P4: PWOM acts as a reducer of third age conservative behavior.

\subsection{Third age consumption behavior in Brazil}

In Brazil, third age income reached $\mathrm{R} \$$ 446 million in 2013, which corresponds to $21 \%$ of the total income of the population (Data Popular, 2013). Approximately one million third age people in Brazil have higher education, live in 
noble areas, and drive luxury cars, among other points (Serasa Experian, 2015).

About $45 \%$ of third age consumers in Brazil are dissatisfied with the low supply of products and services aimed at their age group (Data Popular, 2013). For third age consumers in Brazil, the most desired items are clothes (20\%), followed by cell phones with larger letters/ keyboards (12\%), places to go out and that are frequented by third age people $(9 \%)$, exclusive tourism (7\%), beauty products (3\%), and makeup (2\%) (SPC Brasil, 2014).

Also according to SPC Brasil (2014), saving money does not feature among the plans of practically half of the third age interviewees. This is because $49 \%$ say they care more about enjoying life than saving. The new priorities of third age individuals have probably led to this change. For them, having fun is fundamental. For $46 \%$ of the interviewees, leisure has become a much more frequent activity than before (rising to $51 \%$ among those with higher education) (SPC Brasil, 2014). Going out for a walk, for example, is a habit assumed by $41 \%$ of the sample and by $48 \%$ of those with higher education.

The socialization issue also appears to be prominent, with one in four claiming to spend a significant part of their time in the company of friends (31\% among those in the A/B class) (SPC Brasil, 2014). It is also noteworthy that almost $20 \%$ of the respondents interviewed by SPC Brasil (2014) say that they have increased their spending on travel services compared to before. For those belonging to class $\mathrm{A} / \mathrm{B}$, this number jumps to $33 \%$.

\section{Methodological Procedures}

\section{I Data collection and sample characteristics}

A qualitative approach was used to cover in depth the social phenomena, with the aim of identifying meanings and relations (Denzin \& Lincoln, 1994). The present research focuses on the receiver of PWOM regarding leisure activities, by means of an interpretation of the participants' spontaneous motivations and perceptions, and two data collection techniques were applied: indepth interviews and audio diaries.

Due to the difficulty in accessing respondents from the age group targeted to participate in the research, we followed Creswell's (1998) suggestion of a minimum of 5 participants for phenomenological research. Additionally, according to Bacha, Strehlau, and Perez (2006), due to this segment encompassing a large age range of approximately 30 years, it is usual to distinguish between two groups: the lower age group of the elderly and the high senior age group. Moschis (1996) argues that chronological definitions need to be put in an appropriate perspective. For instance, researchers or companies focused on nursing homes should concentrate on the high senior age group. In the case of companies or studies targeting leisure services, these should focus on the lower age group of the elderly (Moschis, 1996). Following this consideration and Creswell's (1998) sampling recommendation, the present research targeted third age individuals aged between 60 and 70 years old, who are residents of São Paulo state, in Brazil. For the audio diaries, the selection criteria include the third age participant's ability to handle smartphones and applications such as WhatsApp.

After some frustrated attempts to access respondents using the author's social network, other options were tested such as social clubs and public social leisure and sports organizations. Finally, one public organization located in the São Paulo state city of Valinhos, called the Municipal Center of Coexistence of the Elderly, provided access to its third age members. At the beginning of sport and dance classes, the third age individuals were invited to participate in the research. After visiting five classes, 11 individuals accepted to participate in the in-depth interviews, which were carried out on a face-to-face basis during the months of June and August of 2017. The audio diary participants were given a 30-day deadline to report their experiences via an audio 
diary. A sample of 28 people was contacted and received instructions on participating in the research. Of these, seven individuals received a recommendation for leisure services within the stipulated period during the months of June and August of 2017. They sent their audio records through the WhatsApp application describing the recommendations they had received. Moylan, Derr, and Lindhorst (2015) argue that future studies may consider using smartphones with a recording functionality. These are lightweight and highly portable, easily rechargeable, and familiar to most participants.

Previously and exclusively for the indepth interviews, the participants completed a critical incident form (Appendix A) to generate more detailed discussions regarding PWOM, in accordance with a prior study of WOM receivers (Sweeney et al., 2008). The form was based on the questions used in the critical incidents study from Bitner, Booms, and Tetreault (1990).

The interviews used a semi-structured script (Appendix B) aiming to explore the participant's experiences and the meaning they give to these experiences (Seidman, 2013). In this sense, the script explored the PWOM receiver's experiences and perceptions taking into account the four analytical research propositions. It was formed of 17 questions to guide the interview flow and, as suggested by Yom (1994), they were formulated as openly as possible. This gives the participant the freedom to teach the interviewer things they did not know, while ensuring that the desired information is obtained. In both instruments, the in-depth interviews and the audio diaries, the participants were required to mention an example of PWOM but it was not specified whether it was given spontaneously or asked for by the receiver.

The respondents received some clarification concerning examples of leisure activities, which include classes (e.g., gym, dance), travel (e.g., agencies, cruises), accommodation (e.g., hotels, resorts), food and drink (e.g., restaurants, bars), music (e.g., shows, concerts), the movie theater, the theater, and others. As presented in section 4 , the most cited leisure activities were related to those mentioned here.

While the first technique, the in-depth interviews, sought memories of recommendations, the audio diaries looked for participants' experiences in real time and context (Bolger, Davis, \& Rafaeli, 2003). According to Breakwell (2012), the audio diary occurs without mediator presence. Thus, participants are able to elaborate on the questions freely and spontaneously. It can provide particular benefits when behaviors are the focus of the research (Breakwell, 2012).

On the other hand, is important to emphasize that when an open method is used to narrate experiences, some participants may express difficulty in capturing all aspects of their experiences. This is an issue that needs to be considered in the use of audio diaries as a data collection technique (Brocki \& Wearden, 2006).

\subsection{Content analysis procedures}

By means of the theoretical framework present in the study, pre-defined deductive categories, passive of changes, were described (Ryan \& Bernard, 2000). According to the authors, in this model, the researcher raises categories deductively from the literature review. The data collection structure and the analysis proceedings followed Miles, Huberman, and Saldana (2019), requiring data collection based on analytical categories to carry out the content analysis. In the first cycle, coding was defined as "a way to initially summarize segments of data" (Miles et al., 2019) and the data was coded based on four themes: risk associated with consumption, purchase decision making, service quality perception, and conservative purchase behavior. From the second cycle coding, subcategories emerged corresponding to each main theme, such as general, financial, physical, and emotional risk associated with consumption risks. Also, engagement, relief and comfort, and knowledge were associated with the purchase decision category. In the conservative purchase 
behavior category, the subcategories were social network, confidence, positive expectation and curiosity, and enthusiasm.

The study undertook content analysis to process the data. The in-depth interviews and audio diaries were transcribed and the NVIVO software (version 12.4.0) was used for text codification and analysis. First cycle coding was assigned to each paragraph. Then, the data were reduced and patterns generated subcategories (second cycle coding) representing these codes, and, finally, the themes were validated and refined through raw data reviewing (Miles et al.).

In order to check the data quality, the researchers followed the three criteria suggested by Miles et al.: 1) checking for representativeness; 2) checking for researcher effects on the case, and vice versa; and 3) triangulating across methods. Regarding representativeness, the individuals interviewed using the two methods really corresponds to the group aged between 60 and 70 years old in Brazil, capturing diverse economic and social backgrounds (please check section 4.1 and Appendixes D and E detailing the interviewee profile). Concerning the possible bias from researcher effects on the case and vice versa, the researchers were not directly emotionally or professionally linked to the respondents. As pointed out earlier, the third age individuals participated voluntarily and were recruited and selected following objective criteria previously determined for the field research protocol. In order to check the applicability and to better match the script instrument and the critical incident form with the interview's language and context, a pre-test was performed with three third age participants living in the city of São Paulo. This also helped to highlight strong and weak points of the questions as well as possible improvements. In terms of data triangulation, the audio diaries were planned to serve as a checking instrument for the in-depth interviews, aiming to find outliers or contradictions, and also to help support the evidence derived from using the other technique.

\section{Results and Findings}

Figure 3 highlights the subcategories that emerged from the NVIVO content analysis according to the coded cases (nodes that represent the units of observation: interviews and audio diaries) and coding references (total number of references). All four categories were mentioned by the majority of participants, with most citations concerning PWOM as a reducer of conservative purchase behavior.

In the consumption risk category, the subcategories related to safety were found in general, physical, emotional, and financial derivations. In the purchase decision-making category, subcategories such as engagement and relief/comfort were observed. In relation to the quality perception category, a single subcategory was detected: knowledge acquirement. Finally, in the third age conservative behavior category, the subcategories social network, confidence, positive expectation/curiosity, and enthusiasm were identified.

Figure 3 shows the relative importance of each category expressing the participants' perceptions regarding PWOM. It is important to highlight that the segment sizes in Figure 3 are equivalent and proportional to the frequency of coded cases (units of observation). The frequency of coded cases, in summary, represents the number of interviews and audio diaries where each category was perceived. 


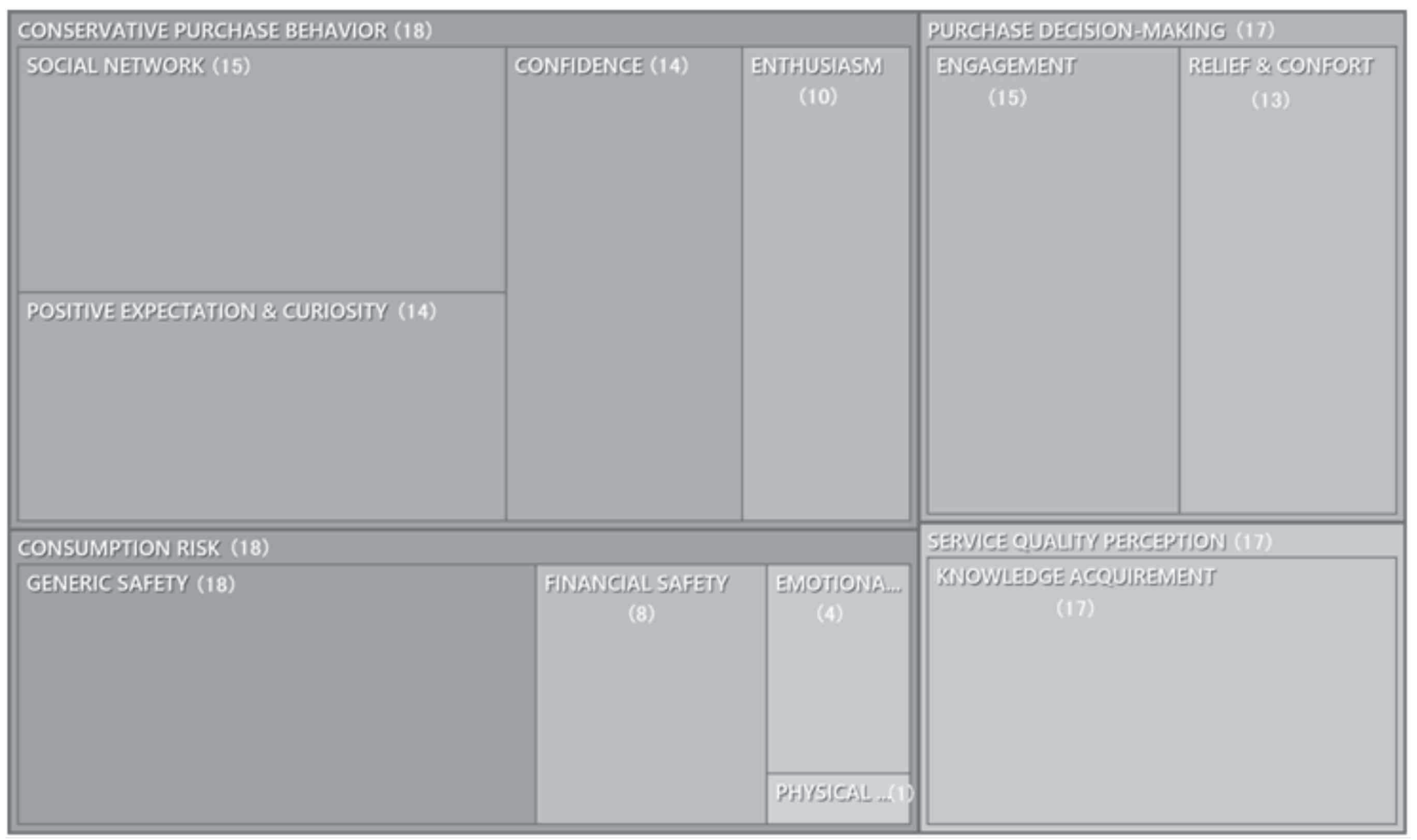

Figure 3. Main findings of the NVIVO content analysis according to *coded cases.

* = nodes that represent units of observation (interviews and audio diaries)

()$=$ number of coded cases for each category

\section{I Respondents and PWOM profile}

The sample of respondents met the sampling criteria, namely belonging to the age group between 60 and 70 years old, being a mix of both men and women, living in the cities of São Paulo and Valinhos, covering a variety of occupations and education levels, from high school to doctorate, and having a family income range from $R \$ 3,000$ to $R \$ 30,000$, respectively. A more detailed profile is presented in Appendixes $\mathrm{D}$ and $\mathrm{E}$.

In general, the respondents participate in two to fifteen WhatsApp groups. Therefore, they mostly receive few recommendations, which may support the theoretical proposition that third age people are more socially isolated and therefore receive less social influence in relation to leisure options (East et al., 2014).

Most of the PWOM received by the participants concerned leisure services related to food and drink, travel, and dancing. Subsequent consumption of the services by the receivers occurred in most cases of the PWOM, with the exception of two interviewees who did not consume due to a lack of time or financial conditions.

Most of the PWOM received by the participants was sent by friends, with the exception of seven recommendations that were received from relatives. There was no apparent difference in terms of consumption between recommendations from a friend and those from a relative.

Most of the interviewees remembered the approximate date they received the recommendations. For these participants, the majority of the PWOM was received about two years before the research. This reinforces the assertion of East et al. (2014) described previously in this study, that the recommendations received by men and women fall substantially among the elderly. 
Also, a significant nexus was found between the relevance of the recommendations and the fact that they were given by people trusted by the receiver.

No significant differences were found between the two techniques - in-depth interviews and audio diaries. Thus, the same subcategories interpretation initially used for the interviews was also used for the audio diaries.

The main conclusions regarding the importance of PWOM in leisure services consumption by the age group between 60 and 70 years old are described below. Also, important quotes were added to each subcategory.

\subsection{PWOM acts as a reducer of service risk perception}

The feeling of safety generated by PWOM proved to be fundamental in the purchase decision process of third age receivers and appeared extensively in the study.

This is consistent with the affirmations of Roselius (1971) and Settle and Alreck (1989) that WOM has been recognized as a key reducer of various forms of risk, such as, for instance, functional, financial, psychological, and social risks. According to Wangenheim and Bayón (2004), in general, these types of risks can be classified into two major groups: functional or financial risk and psychological risk. As for psychological risk, there is a relationship with low self-perception, when the consumer makes a bad choice. It is the inherent risk of experiences that cast doubt on the ability to execute successful choices (Wangenheim \& Bayón, 2004).

WOM should have greater relevance in services consumption, since it helps to reduce the risk associated with such situations (Ennew et al., 2000; File et al., 1994).

In the present research, derivations were observed of feelings of safety generated by recommendations. In addition to the financial safety mentioned in the literature investigated, two additional subcategories were identified: physical safety and emotional safety.
PWOM was ratified as a consumption risk reducer for this age group. The idea of safety generated for third age receivers of recommendations is a fundamental element in their consumption decisions.

The financial safety generated by PWOM is related to the misuse of money, the financial importance of a bad purchase, and the availability of products offering a better cost-benefit (Wangenheim \& Bayón, 2004).

Physical safety appeared to a lesser extent. It refers to possible mobility difficulties in regard to services recommended to third age individuals.

Finally, it was also possible to observe, to a lesser extent, the emotional safety generated by PWOM among third age receivers. It relates to the fact that receivers of recommendations are emotionally affected, since WOM is known to convey new experiences that are enjoyable when positive.

Some participants' comments illustrate all three safety issues concerning PWOM as a risk reducer:

\#I3 "It [PWOM] helped, because it was somewhere I wanted to go, but at the same time, I was afraid to go.[...] [PWOM] is very important to me, I think for all people my age, because we don't have the time or the conditions to get burned really bad, you know? (laughs)."

\#I2 "The recommendation influenced me because he said: 'you will pay a little bit more, but the accommodation is much better.' He explained everything."

\#AD3 "As for this type of risk [financial loss, money misuse], [the PWOM] totally resolved it. After the explanation, I knew that there was no risk: I could go, I would pay the right price, fair, it would be good, and I would feel good."

\#I1 “... when you're younger, you venture out more, but when you're older you want to go somewhere you know will work out. So, the question of PWOM has an even greater weight when you're older. When you're young, you're more willing to venture out, you do not have so many food problems, and you can eat and drink 
anything. Now, when you're older, you usually have some dietary restrictions and so one."

\subsection{PWOM acts as an ally in the purchasing decision process}

PWOM plays a relevant role in third age purchase decisions. Engagement and relief/ comfort generated by PWOM in receivers aged between 60 and 70 years old are important in the purchasing decision process.

According to Sweeney et al. (2008), the content of the message in WOM is critical, given its potential in making the communication more persuasive. In the emotional field, there is a suggestion that vivid, interesting, provocative, or attention-getting information is more accessible in the memory, as it weighs heavily on cognitive analysis and has a greater impact on judgments (Herr et al., 1991; Kisielius \& Sternthal, 1986). Sundaram et al. (1998) also defend the rational dimension of WOM, since a series of consumer experiences describe message content according to performance, response to problems, and price perceptions.

The engagement and relief/comfort found in this research and generated by PWOM play important roles in the purchase decisionmaking process for third age receivers, appearing extensively in the study. The engagement identified refers to the involvement and commitment of the third age receiver in the decision process for leisure service consumption. Meanwhile, the relief/ comfort refers to receivers' feelings generated by PWOM, acting as a facilitator and leading to a lighter and easier decision-making process.

Some participants' comments illustrate the issues mentioned concerning PWOM as an ally in the purchasing decision process:

\#AD4 "It [the recommendation] influenced [the decision]. The PWOM greatly influenced [the decision]. It even seduced me to make the decision, because the way it was influencing, we were discussing more and more trip details, driving me more and more to go on that trip. [...] I concluded that the decision was good. [...] In the details he provided me day by day, more and more [...] and quite firmly that I was not going to go wrong."

\#AD6 "Yes. If she had said it [PWOM] once I would have already memorized it: a thing to be tried. But after two or three times, then it's something that has to be checked out. "

\#I1 "I think it [the decision making] was facilitated by the PWOM."

\# I3 "I felt comfortable [in terms of the feeling generated by the PWOM]."

\subsection{PWOM act as an attestation of perceived service quality}

Recommendations are fundamental to service quality perception. Knowledge provided by PWOM to receivers aged between 60 and 70 years old is fundamental to consumption decisions.

WOM also has a rational dimension. Consumers provide detailed messages regarding products and services through WOM, allowing the receiver to develop rational perceptions of the product. This significantly influences the perception of the company's reputation (Allsop et al., 2007).

The knowledge acquired through PWOM is relevant to the third age purchase decision process and appear to be strong in the study. Recommendations prove to be a source of knowledge for the third age receivers. Detailed messages allow receivers to develop cognitive judgments and rational perceptions. This significantly influences quality perception and service reputation.

Some participants' comments illustrate the findings concerning PWOM as an attestation of perceived service quality:

\#AD4 "The information he [the sender of PWOM] gave me greatly influenced the perception [of quality], even about company reputation, because he said: 'There the people are bona fide, there are no mistakes, and it's all well explained."”

\#AD1 "Yes [the PWOM influenced the service quality perception], because there was 
information about price, hygiene, service, place, address, if it is accessible. [...] Yes, of course! Person [the sender of the recommendation] was satisfied, [so] I believed that I would also be."

\#AD5 "Yes, [the PWOM contained] the complete description of the place, the ambience, and the service [...] Yes, [it influenced the service quality perception], she [the sender of the recommendation] spoke and was very eloquent about the service."

\subsection{PWOM acts as a reducer of third age conservative behavior}

PWOM plays an important role in third age conservative behavior. Social networks, confidence, positive expectations/curiosity, and enthusiasm generated by PWOM attenuate this behavior in receivers.

The social network generated by PWOM proved to be fundamental in regard to third age conservative purchase behavior and appeared categorically in the study. It refers to questions that social influence by means of PWOM can induce and how it can assist consumers in their purchase decisions, especially third age people, because they are more socially isolated and have less information for decision making (East et al., 2014).

The confidence generated by means of PWOM in the consumer decision process also proves to be incisive in relation to third age conservative purchase behavior. It is a reflection of the receiver's trust in, proximity, and affectivity with the sender.

Third age people tend to experience more activation of their emotional centers, leading to a focus on affective information as age advances (East et al., 2014). According to Drolet et al. (2010), it refers to third age people tending to have greater social-emotional selectivity, resulting in a focus on affective information in the present and in the near future. Thus, there is greater attention paid to established emotional contacts and less attention paid in obtaining new information sources, which results in third age consumers focusing on the people they know well (Drolet et al., 2010).

The positive expectation/curiosity and enthusiasm aroused in receivers of PWOM is more relevant for third age participants, but less so when compared to the subcategories described above.

Emotions play an important role in the transmission and reception of WOM (Söderlund \& Rosengren, 2007). Another component related to the emotive aspect of recommendations is the energy used to deliver the message (Mazzarol et al., 2007). WOM is best remembered because of the liveliness inherent in face-to-face interactions (Herr et al., 1991).

Positive expectations/curiosity refers to receivers' feelings generated by PWOM and is important for conservative purchase behavior. Likewise, the enthusiasm generated by means of PWOM also appears to be less incisive in relation to conservative purchase behavior among third age receivers, but it is still relevant. Some participants' comments illustrate the findings concerning PWOM as a reducer of third age conservative behavior:

\#I4 "Yes, of course it had an influence [the fact the PWOM came specifically from that person]. That's what I'm saying to you: when it comes from a friend ... a friend is someone who usually has the same tastes or at least the same perspectives on life. Therefore, when a friend sends PWOM, you take it into consideration, because theoretically they belong to the same socioeconomic and cultural range as yours."

\#I4 "[The fact that the PWOM came specifically from this person helped in the decision] both rationally and emotionally. This person knows me."

\#I1 "Of course [it supports the decision], there being a positive assessment by someone I trust ..."

\#I8 "[The PWOM generated] a positive expectation ...”

\#I2 "It was a feeling of expectation [generated by the PWOM]. [...] As he said it 
was good, it gave me the expectation that I would go and say: 'This is exactly as he said it was.' We will see."

\#AD6 "Yes, [the PWOM] had vibrant, exciting [information] because it [generated] curiosity on my part. I was curious to see the place."

\#AD4 "I was quite emotionally involved, because I read the message [PWOM] that he passed to me, I understood the message he was passing. He was excited. It conveyed this excitement to me, so I was quite euphoric in my decision-making. [...] I was getting that [PWOM] with positive energy."

\#I3 "Yes [it is better to make a decision by means of social contact with another person rather than in a solitary way], because often when I've decided on my own, I've got burned really badly."

\#I8 "Yes, it [social interaction by means of PWOM] certainly helped. The recommendations come from friends, from close people with whom I live. Recommendations from these people, besides being quality indications, represent opportunities to have social interaction with these people."

\subsection{Discussion and additional results}

The study also manages to identify additional findings beyond the original research objectives. These results are summarized below.

- The fact that recommendations were issued by close, trustworthy people or ones with affective ties with the third age receiver proved to be relevant to their consumption decision. This factor plays an important role in the purchase decision-making process and conservative purchase behavior of this age group studied. The result supports East, Hammond, and Lomax's (2008) findings that PWOM and NWOM have more impact when derived from close ties and they are more significant when associated with other variables such as strength of expression.

- However, it was observed to a lesser extent that third age receivers with a friendly and sociable personality, who are less distrustful of others, are less susceptible to this question.

- It was possible to observe little or limited importance of PWOM for third age receivers with a rational or pragmatic personality.

- The volume of recommendations received by third age individuals, more specifically by the age group studied of between 60 and 70 years old, appears to be low. The PWOM regarding leisure services was received by participants in a period prior to the data collection, ranging from one and a half to seven years. Overall, the participants reported that they receive few recommendations.

Table 1 provides a broad overview of the conceptual framework of the research and the main findings that are presented as new propositions. Additionally, the table also mentions practical implications corresponding to each new proposition. The research findings enabled a better understanding of the effect of PWOM over third age consumer behavior relating to service purchasing. 
Table 1

Research conceptual framework and the main findings

\begin{tabular}{|c|c|c|c|}
\hline \multicolumn{4}{|c|}{ Final research propositions } \\
\hline Theoretical Propositions & References & $\begin{array}{l}\text { Findings / New Propositions } \\
\text { (data collected) }\end{array}$ & Practical Implications \\
\hline $\begin{array}{l}\text { Consumption risk } \\
\text { (PWOM acts as a reducer of } \\
\text { perceptions of service risk) }\end{array}$ & $\begin{array}{l}\text { Ennew, Banerjee, and Li } \\
\text { (2000); File, Cermak, and } \\
\text { Prince (1994); Murray } \\
\text { (1991); Wangenheim and } \\
\text { Banyón (2004); Woodside } \\
\text { and Delozier (1976); Roselius } \\
\text { (1971); Settle and Alreck }\end{array}$ & $\begin{array}{l}\text { General safety: PWOM reduces } \\
\text { general consumption risk. }\end{array}$ & $\begin{array}{l}\text { Managers' strategies should } \\
\text { recognize that due to the nature } \\
\text { of services, these are more } \\
\text { difficult to assess, and therefore } \\
\text { the safety issue becomes critical } \\
\text { in the purchasing decision } \\
\text { process. }\end{array}$ \\
\hline
\end{tabular}

Financial safety: PWOM reduces financial risk. It is linked to the misuse of money, the financial importance of a bad purchase, or the availability of products offering a better cost-benefit.

Physical safety: PWOM reduces physical risk. It refers to locomotion issues, mobility difficulties, non-safe areas, and poor venue structure of services.

Emotional safety: PWOM reduces emotional risk. It refers to the fact that receivers of recommendations are emotionally affected, since word-of-mouth is known to convey new experiences that are enjoyable when positive.

Purchase decision-making Allsop, Baset, and Hoskins (PWOM acts as an ally in the (2007); Herr, Kardes, and purchase decision process).
(2007); Herr, Kardes, and
Kim (1991); Kisielius and Sternthal (1986); Söderlhund and Rosengren (2007); Sundaram, Kaushik, and Webster (1998).

\section{Engagement: PWOM generates} engagement in the purchase decision-making process. It is linked to involvement in and commitment to the decision process.

Feelings of relief and comfort: PWOM generates feelings of relief and comfort in the decisionmaking process. It refers to receivers' feelings, acting as a facilitator in the decision-making process.
Managers can boost feelings of safety in third age people by means of recommendations that clearly convey the price/quality relationship of their services.

Managers can boost feelings of safety in third age people by means of recommendations that clearly convey locomotion, accessibility, mobility, medical area structure, and safe area issues for service consumption.

Managers can boost feelings of safety in third age people by means of recommendations that clearly convey new and pleasant experiences that generate positive feelings.

Decision makers should focus on communication that will emotionally and rationally assist third age people. Engagement generated by PWOM that includes these factors is important in third age receivers' purchasing decisions.

Decision makers should focus on communication that will emotionally and rationally assist third age people. Relief generated by PWOM that includes these factors is important in third age receivers' purchasing decisions. 


\begin{tabular}{lll}
\hline & & \multicolumn{1}{c}{ Final research propositions } \\
\hline Theoretical Propositions & References & $\begin{array}{l}\text { Findings / New Propositions } \\
\text { (data collected) }\end{array}$ \\
\hline $\begin{array}{l}\text { Service quality perception } \\
\text { (PWOM acts as an ally of }\end{array}$ & $\begin{array}{l}\text { Allsop et al. (2007); Liljander } \\
\text { and Strandvik (1995); }\end{array}$ & $\begin{array}{l}\text { Knowledge acquirement: PWOM } \\
\text { generates knowledge and detailed }\end{array}$ \\
service quality perception). & $\begin{array}{l}\text { Mazzarol, Sweeney, and Soutar } \\
\text { (2007); Tax, Chandrashekaran }\end{array}$ & $\begin{array}{l}\text { information in regards to the } \\
\text { service. Detailed descriptions allow } \\
\text { and Christiansen (1993). }\end{array}$ \\
& $\begin{array}{l}\text { receivers to develop cognitive } \\
\text { judgments and rational service } \\
\text { perceptions. This significantly } \\
\text { influences quality perception and } \\
\text { service reputation. }\end{array}$
\end{tabular}

Practical Implications

Companies can also add value

to word-of-mouth by means

of detailed service messages

that allow third age receivers to

develop cognitive judgments

and rational perceptions.

This greatly influences the perception about the quality and reputation of the service and, consequently, of the company. When they have detailed information, third age consumers are better able to decide or act as senders of recommendations as well.

Conservative purchase behavior

(PWOM acts as a reducer of third age conservative behavior).

\author{
Anderson (1998); Drolet, Lau- Social network: PWOM generated \\ Gesk, Williams, and Jeong \\ (2010); East et al. (2014); \\ Pandraud, Laurent, and \\ Lapersonne (2005); Lambert- \\ Pandraud and Laurent (2010); \\ Myers and Lumbers (2008); \\ Phillips and Sternthal (1977); \\ Wallach and Kogan (1961). \\ by social networks reduces \\ conservative purchase behavior \\ since third age people are more \\ socially isolated and have less \\ information for decision-making.
}

Marketing managers should develop communication strategies designed to mitigate the conservative behavior of third age consumers, They can apply social influence principals by means of recommendations to induce and assist elderly consumers in their consumption decisions since they are, to a certain extent, more socially isolated and have less information for decision making.

Confidence in the sender: PWOM generated by people that are trusted by third age receivers reduces their conservative purchase behavior. It is a reflection of the receiver's confidence in and proximity and affectivity with the sender. Greater attention is paid to established emotional contacts and less attention in obtaining new information sources, which results in third age consumers focusing more on the people they know well and trust.

Positive expectation and curiosity: PWOM that generates positive expectations and curiosity in third age people reduces their conservative purchase behavior. The expectation and curiosity lead to open-minded behavior toward the purchase intention.

Enthusiasm: PWOM that generates enthusiasm in third age people reduces their conservative purchase behavior.
Managers should work with senders of recommendations that third age consumers know well, for instance, public figures and influencers who inspire confidence, with proximity to or affective ties with third age individuals.

Marketers should include in recommendations messages that arouse expectations, enthusiasm, satisfaction, and curiosity in third age consumers. For instance, they should maximize the strength of positive messages, generate positive brand perceptions, and convey vibrant or impactful information that awakens the attention and positivity of this age group. 


\section{Conclusion}

The importance of WOM in marketing is widely accepted as an important driver of the decision-making process, reducing consumption risk and increasing perceptions of service quality. For third age consumers, WOM is as key component in reducing conservative purchase behavior. The research findings of the present paper, which aimed to identify why PWOM is important in leisure services consumption by third age consumers, broaden the understanding of how the receivers are affected both emotionally and rationally and show the importance of recommendations to third age citizens.

The main results indicated that PWOM is an important marketing tool for primarily reducing the conservative purchase behavior as well as the consumption risks associated with leisure services, such as financial, emotional, and even physical constraints. Physical risk appeared as a new component not yet explored by prior studies. For third age citizens, many structural factors matter for safety and physical comfort, such as accessibility, quietness, and a soft pace, among others.

In terms of conservative purchase behavior, the findings showed that familiarity with the PWOM sender and their trustworthiness were key elements for reducing third age conservative behavior, which is aligned with previous studies (Mahapatra \& Mishra, 2017; Martin \& Lueg, 2013). Although the literature has pointed to the vanishing of social ties among the third age population, the results indicated that access to digital social networks such as Facebook or WhatsApp have given them a more active position to enhance WOM opportunities. Also, PWOM acted as trigger of physiological states such as enthusiasm and curiosity, leading to open-minded behavior regarding purchase intention.

Additionally, the results evidenced that PWOM might enhance service quality perception, as proposed by prior researchers. From the third age consumer perspective, PWOM emerged as an important tool to acquire knowledge concerning recommendations. As postulated by Sweeney et al. (2014), PWOM fosters consumer education. Especially for elderly consumers, the nature of the service and details of its offering convey important cognitive input to reduce anxiety, fear, or any emotional constraints.

The purchase decision-making process for third age people involves some particularities and the findings highlighted the two most prominent emotional aspects considered by this target group: involvement and feelings of comfort. The purchase of a leisure service might be an adventurous task involving a variety of associated risks. In this sense, PWOM works as an ex ante safeguard, preventing the receiver from experiencing unexpected or unpleasant situations. Also, PWOM softens the purchase decision process and in certain circumstances it seduces the third age person to act more proactively toward the service acquisition.

Accordingly with the results of Söderlund and Rosengren (2007) and East, Hammond, and Lomax (2008), the findings also demonstrated that emotional content plays an important role in the transmission and reception of WOM, particularly among the third age group.

\section{I Practical implications}

From a practical standpoint, the research findings show that PWOM plays an important role in the decision-making process and conservative purchase behavior of third age consumers. By means of WOM, companies can help their senior customers simplify their choices and motivate their consumption decisions as well as engaging them with the brand or service in question.

Managers' strategies should recognize that due to the nature of services, these are more difficult to assess, and therefore the safety issue in the purchasing decision process becomes critical. Managers can boost feelings of safety in seniors by means of recommendations that clearly convey the price/quality relationship of their services, mobility issues for service consumption, as well 
as new and pleasant experiences that generate positive feelings.

Decision makers should focus on communication that will emotionally and rationally assist third age consumers. Engagement and relief generated by PWOM that includes these factors are important in the purchasing decisions of receivers in this age group.

Companies can also add value to WOM by means of detailed service messages that allow receivers to develop cognitive judgments and rational perceptions. This has an important influence on perceptions about quality and the reputation of the service and, consequently, of the company. When they have detailed information, third age consumers are better able to decide or act as senders of recommendations as well.

Marketing managers should also develop communication strategies designed to mitigate the conservative behavior of third age consumers. They can apply social influence principles by means of recommendations to induce and assist elderly consumers in their consumption decisions since they are, to a certain extent, more socially isolated and have less information for decisionmaking. Also, they should work with senders of recommendations that senior consumers know well, for instance, public figures or influencers who inspire confidence and have proximity to or affective ties with third age individuals.

This research suggests that marketers should include in recommendations messages that arouse enthusiasm, positive expectations, and curiosity among senior consumers. For instance, they should maximize the strength of positive messages, generate positive brand perceptions, and convey vibrant or impactful information that raises the attention and positivity of the third age consumer.

As far as public management is concerned, governments can likewise use the strategies described to exert influence over the elderly segment. Public managers are responsible for many actions that influence the population, with respect to social, education, and health issues. In some circumstances, properly communicated recommendations can help implement public policy.

\subsection{Research limitations and future studies}

In regard to the research limitations, the delimitations such as the age group, receivers of recommendations, and leisure services, do not allow for the unrestricted applicability of the conclusions to other categories of services and consumers. However, the research findings could be relevant to other services categories focused on the third age, such as, for instance, health, life insurance, nursing homes, banking, and private pension services.

It is possible that the selection criteria for respondents applied in this research (familiarity with a smartphone and WhatsApp) might have led to the exclusion of relevant participants. These criteria can be better analyzed in future research.

It is important to note that the audio diaries were recorded and sent by the participants at the moment of receiving the PWOM. Due to the research time limits, there was no confirmation of the consumption of the recommended service. Also, the preparation, interpretation, and inferences of the phenomena were based on the researchers' interpretative capacity.

For upcoming research, we suggest focusing on the receiver by considering other variables such as the consumer segment, type of service or product and, especially, the media used to transmit the recommendation. This information might enhance the understanding of the social phenomena involving elderly consumer behavior motivated by WOM.

Considering contemporary technological media, it is also important to compare the importance of recommendations made to elderly receivers when sent via different media, especially via social media such as Facebook and Instagram. 


\section{References}

Allsop, D. T., Basset, B. R., \& Hoskins, J. A. (2007). Word-of-mouth research: Principles and applications. Journal of Advertising Research, $47(4), 398-411$.

Anderssen, T. W., \& Lindestad, B. (1998). Customer loyalty and complex service. International Journal of Service Industry Management, 9(1), 7-32.

Anderson, E. W. (1998). Customer satisfaction and word of mouth. Journal of Service Research, 1(1), 5-17.

Arndt, J. (1967). Word of mouth advertising: A review of the literature. New York: Advertising Research Foundation.

Bacha, M. L., Strehlau, V. I., \& Perez, G. A. (2006). Compreensão do significado do termo terceira idade pela terceira idade em São Paulo. Anais do Encontro de Marketing da Associação Nacional de Pós-Graduação e Pesquisado em Administração, Rio de Janeiro, RJ, Brasil. 2. Retrieved from http://www.anpad.org.br/admin/ pdf/ema2006-mktb-391.pdf

Baker, A. M., Donthu, N., \& Kumar, V. (2016). Investigating how word-of-mouth conversations about brands influence purchase and retransmission intentions. Journal of Marketing Research, 53(2), 225-239.

Berger, J. (2014). Word of mouth and interpersonal communication: A review and directions for future research. Journal of Consumer Psychology, 24(4), 586-607.

Bitner, M. J. Booms, B, H., \& Tetreault, M. S. (1990). The service encounter: Diagnosing favorable and unfavorable incidents. The Journal of Marketing, 54(1), 71-84.

Bolger, N., Davis, A., \& Rafaeli, E. (2003). Diary methods: Capturing life as it is lived. Annual Review of Psychology, 54, 579-616.
Boulding, W., Kalra, A., Staelin, R., \& Zeithaml, V. A. (1993). A dynamic process model of service quality: From expectations to behavioral intentions. Journal of marketing research, 3O(1), 7-27.

Breakwell, G. M. (2012). Diary and narrative methods. In G. M. Breakwell, J. A. Smith, , D. B. Wright (Eds.), Research methods in psychology (pp. 391-410), London: Sage.

Brocki, J. M., Wearden, A. J. (2006). A critical evaluation of the use of interpretative phenomenological analysis (IPA) in health psychology. Psychology and Health, 21(1), 87-108.

Buttle, F. A. (1998). Word of mouth: Understanding and managing referral marketing. Journal of Strategic Marketing, 6(3), 241-254

Carstensen, L. L., Isaacowitz, D. M., Charles, S. T. (1999). Taking time seriously: A theory of socioemotional selectivity. American Psychologist, 54(3), 165.

Cole, C., Laurent, G., Drolet, A., Ebert, J., Gutchess, A., Lambert-Pandraud, R., \& Peters, E. (2008). Decision making and brand choice by older consumers. Marketing Letters, 19, 355-365.

Creswell, John (1998). Qualitative inquiry and research design: Choosing among five traditions. Thousand Oaks: Sage

Instituto Data Popular (2013). Panorama dos Idosos, Retrieved from http://www.ebc. com.br/noticias/brasil/2014/10/idosos-nao-seidentificam-mais-como-pessoas-frageis

Denzin, N. K.; \& Lincoln, Y. S. (1994). Handbook of qualitative research. Thousand Oaks: Sage.

Drolet, A., Lau-Gesk, L., Williams, P., \& Jeong, H. G. (2010). Socioemotional selectivity theory: implications for consumer research. In A. Drolet, N. Schwarz, \& C. Yoon. (Eds.), The aging consumer: Perspectives from psychology and economics (pp. 51-72), New York: Routledge. 
Dye, R. (2000). The buzz on buzz. Harvard Business Review, 78, 139-146.

East, R., Hammond, K., Wright, M. (2007). The relative incidence of positive and negative word of mouth: A multi-category study. International Journal of Research in Marketing, 24(2), 175-184.

East, R., Hammond, K., \& Lomax, W. (2008). Measuring the impact of positive and negative word of mouth on brand purchase probability. International journal of research in marketing, 25(3), 215-224.

East, R., Uncles, M. D., \& Lomax, W. (2014). Hear nothing, do nothing: The role of word of mouth in the decision-making of older consumers. Journal of Marketing Management, east, 30(7/8), 786-801.

East, R., Uncles, M., Romaniuk, J., \& Riley, F. D. O. (2015). Factors associated with the production of word of mouth. International Journal of Market Research, 57(3), 439-458.

East, R., Uncles, M. D., Romaniuk, J., \& Lomax, W. (2016). Measuring the impact of positive and negative word of mouth: A reappraisal. Australasian Marketing Journal, 24(1), 54-58.

Ennew, C. T., Banerjee, A. K., \& Li, D. (2000). Managing word of mouth communication: Empirical evidence from India. International Journal of Bank Marketing, 18(2), 75-83.

File, K. M., Cermak, D. S., \& Prince, R. A. (1994). Word-of-mouth effects in professional services buyer behavior. Service Industries Journal, 14(3), 301-314.

Hartline, M. D., \& Jones, K. C. (1996). Employee performance cues in a hotel service environment: Influence on perceived service quality, value, and word-of-mouth intentions. Journal of Business Research, 35(3), 207-215.
Herr, P. M., Kardes, F. R., \& Kim, J. (1991). Effects of word-of-mouth and product-attribute information on persuasion: An accessibilitydiagnosticity perspective. Journal of Consumer Research, 17(4), 454-462.

Hung, K., \& Crompton, J. L. (2006). Benefits and constraints associated with the use of an urban park reported by a sample of elderly in Hong Kong. Leisure Studies, 25(3), 291-311.

IBGE. (2016). Sintese de Indicadores Sociais. Rio de Janeiro: Autor. Retrieved from http://loja. ibge.gov.br/sintese-de-indicadores-sociais-umaanalise-das-condicoes-de-vida-da-populac-obrasileira-2015.html

Kaplan, L. B., Szybillo, G. J., Jacoby, J. (1974). Components of perceived risk in product purchase: A cross-validation. Journal of Applied Psychology, 59(3), 287-291.

Keller, K. L. (1993). Conceptualizing, measuring, and managing customer-based brand equity. The Journal of Marketing, 57(1), 1-22.

Kisielius, J., \& Sternthal, B. (1986). Examining the vividness controversy: An availability-valence interpretation. Journal of Consumer Research, 12(4), 418-431.

Lambert-Pandraud, R., Laurent, G., \& Lapersonne, E. (2005). Repeat purchasing of new automobiles by older consumers: Empirical evidence and interpretations. Journal of Marketing, 69(2), 97-113.

Lambert-Pandraud, R., \& Laurent, G. (2010). Why do older consumers buy older brands? The role of attachment and declining innovativeness. Journal of Marketing, 74(5), 104-121.

Liljander, V., \& Strandvik, T. (1995). The relation between service quality, satisfaction and intentions. In D. Kunst, \& J. Lemmink (Eds.), Managing Service Quality (pp. 45-63). Vught: Paul Chapman. 
Mahapatra, S., \& Mishra, A. (2017). Acceptance and forwarding of electronic word of mouth. Marketing Intelligence \& Planning, 35(5), 594610.

Martin, W. C. (2017). Positive versus negative word-of-mouth: Effects on receivers. Academy of Marketing Studies Journal, 21(2). Retrieved from https://www.abacademies.org/articles/ positive-versus-negative-wordofmouth-effectson-receivers-6732.html

Martin, W. C., \& Lueg, J. E. (2013). Modeling word-of-mouth usage. Journal of Business Research, 66(7), 801-808.

Mazzarol, T., Sweeney, J. C., \& Soutar, G. N. (2007). Conceptualizing word-of-mouth activity, triggers and conditions: An exploratory study. European Journal of Marketing, 41(11/12), 14751494.

Miles, M. B., Huberman, A. M., \& Saldana, J. (2019). Qualitative data analysis: $A$ methods sourcebook. Sage.

Moylan, C. A., Derr, A. S., Lindhorst, T. (2015). Increasingly mobile: How new technologies can enhance qualitative research. Qualitative Social Work, 14(1), 36-47.

Murray, K. B. (1991). A test of services marketing theory: Consumer information acquisition activities. The Journal of Marketing, 55(1), 10-25.

Myers, H., \& Lumbers, M. (2008). Understanding older shoppers: A phenomenological investigation. Journal of Consumer Marketing, 25(5), 294-301.

Moschis, G. P. (1996). Gerontographics: Life-stage segmentation for marketing strategy development. Westport: Greenwood Publishing Group.

Parasuraman, A. (1987). Customer-oriented corporate cultures are crucial to services marketing success. Journal of Services Marketing, 1(1), 39-46.
Parasuraman, A., Berry, L. L., \& Zeithaml, V. A. (1991). Refinement and reassessment of the servqual scale. Journal of retailing, 67(4), 420.

Phillips, L. W., \& Sternthal, B. (1977). Age differences in information processing: $A$ on the aged consumer. Journal of Marketing Research, $14(4), 444-457$.

Roselius, T. (1971). Consumer rankings of risk reduction methods. The Journal of Marketing, 35(1), 56-61.

Ryan, G. W., Bernard, H. R. (2000). Data management and analysis methods. In: N. Denzin, Y. Lincoln (Eds.), Handbook of Qualitative Research (pp. 769-802), Thousand Oaks: Sage.

Seidman, I. (2013). Interviewing as qualitative research: A guide for researchers in education and the social sciences. New York: Teachers college press.

Serasa Experian (2015). Envelhecendo no século XXI. Retrieved from https://www.serasaexperian. com.br/p/aquisicao-marketing/encontrar-novos clientes $/$ mosaic $\% 20$

Settle, R. B., \& Alreck, P. (1989). Reducing buyers' sense of risk. Marketing Communications, 14, 34-40.

Silverman, G. (2011). Secrets of word-of-mouth marketing: How to trigger exponential sales through runaway word of mouth. New York: Amacom.

Söderlund, M., \& Rosengren, S. (2007). Receiving word-of-mouth from the service customer: An emotion-based effectiveness assessment. Journal of Retailing and Consumer Services, 14(2), 123-136.

SPC Brasil (2014). Hábitos, comportamentos $e$ expectativas da terceira idade. Retrieved from https://www.spcbrasil.org.br/pesquisas/ pesquisa/897

Sundaram, D.S., Kaushik, M., \& Webster, C. (1998). Word-of-mouth 9. In J. W. Alba, \& J. W. 
Hutchinson (Eds.), NA - Advances in Consumer Research (pp. 527-531). Provo: UT.

Sweeney, J. C., Soutar, G. N., \& Mazzarol, T. (2008). Factors influencing word of mouth effectiveness: Receiver perspectives. European Journal of Marketing, 429(3/4), 344-364.

Sweeney, J., Soutar, G., \& Mazzarol, T. (2014). Factors enhancing word-of-mouth influence: Positive and negative service-related messages. European Journal of Marketing, 48(1/2), 336-359.

Tax, S. S., Chandrashekaran, M., \& Christiansen, T. (1993). Word-of-mouth in consumer decisionmaking: An agenda for research. Journal of Consumer Satisfaction, Dissatisfaction and Complaining Behavior, 6, 74-80.

United Nations (2015). Department of economic and social affairs. Population division. Retrieved from http://www.un.org/en/development/desa/ population/theme//ageing/WPA2015.shtml

Wallach, M. A., \& Kogan, N. (1961). Aspects of judgment and decision making: Interrelationships and changes with age. Systems Research and Behavioral Science, 6(1), 23-36.

Wangenheim, F. V., \& Bayón, T. (2004). The effect of word of mouth on services switching: Measurement and moderating variables. European Journal of Marketing, 38(9/10), 1173-1185.

Wien, A. H., \& Olsen, S. O. (2014). Understanding the relationship between individualism and word of mouth: A self-enhancement explanation. Psychology \& Marketing, 31(6), 416-425.

Woodside, A. G., \& Delozier, M. W. (1976). Effects of word of mouth advertising on consumer risk taking. Journal of Advertising, 5(4), 12-19. 


\section{Appendix A - Critical Incident Form}

For illustrative purposes only, some clarifications follow.

\section{Examples of leisure services:}

- classes (e.g., gym, dance)

- travel (e.g., agencies, cruises)

- accommodation (e.g., hotels, resorts)

- food \& drink (e.g., restaurants, bars)

- music (e.g., shows, concerts)

- the movie theater

- the theater

- others.

\section{PWOM definition:}

Positive feedback, approval, praise for a service.

1. Name, nationality, and age of respondent?

2. Do you receive many or few service recommendations? Describe.

3. Do you have WhatsApp? Approximately how many groups do you participate in?

4. Think of PWOM you have received about leisure services, if possible, in the last 6 months.

5. When, where, and in what form did this recommendation take place?

6. Briefly describe the PWOM received.

7. What specific circumstances led to this recommendation?

8. What exactly was said by the sender during the PWOM?

9. What did you say or do when you received the recommendation? How did you react?

10. Did the recommendation help you in any way? What made you feel satisfied with the recommendation?

11. After receiving the recommendation, did you consume or intend to consume the service in question?

12. After consumption, were the recommendations reliable in regard to what was actually obtained? 


\section{Appendix B - Interview Script}

1. What is your level of relationship with the sender of the recommendation?

2. Services are usually difficult to evaluate before purchasing. Did the PWOM you received influence your evaluation of the service in question? How?

3. In general, did you feel that your choice process involved a lower risk since the service was previously recommended?

4. During the process of choosing or purchasing a service there is functional risk, for instance the risk of the service not meeting the needs. Did the recommendation reduce this risk in any way?

5. Choosing a service involves financial risk, for instance the risk of financial loss. Financial loss is related to the amount spent on a poor purchase or the availability of products offering a better price/quality ratio. Did the PWOM reduce in any way this risk of wasting money?

6. When choosing a service there is social risk, which is the risk of the negative consequences of a poor choice in relation to your social environment. For instance, a particular brand or service may not be accepted by your friends and acquaintances, and bad choices may call into question your ability to make successful choices. Did the recommendation of the service somehow reduce this risk?

7. Did the PWOM about the service rationally aid your decision making? How would you explain this?

8. Did the PWOM emotionally aid your decision making somehow? How would you explain this?

9. After receiving the recommendation, did you feel that it reduced some discomfort in the decision making? How?

10. Did the recommendation generate any positive or pleasant emotion in you that influenced your decision making?

11. Did the recommendation contain detailed information about the service? Did these details assist you somehow in making the decision to choose or purchase the service? How?

12. Did the recommendation contain vibrant or impactful information that aroused your attention? Did this in any way influence your judgment about the service? How?

13. Did the information in the recommendation you received have any influence on your perception of the quality of the service? How?

14. Did the information in the recommendation have any influence on your perception of the reputation of the company providing the service? Describe. 
15. Have you ever received any other recommendation from this person before? Was this recommendation valid and did it help you? Could you say that you trust this person and their recommendations?

16. Would you say that the fact that the recommendation came specifically from this person emotionally aided your decision in some way? How?

17. Upon receiving a recommendation you have somehow interacted socially with another person. Did the fact that you did not have to decide alone, but by means of social influence, somehow aid your decision making? Describe. 


\section{Appendix C - Audio Diary Guidelines and Script}

For illustrative purposes only, some clarifications follow.

\section{Examples of leisure services:}

- classes (e.g., gym, dance)

- travel (e.g., agencies, cruises)

- accommodation (e.g., hotels, resorts)

- $\quad$ food \& drink (e.g., restaurants, bars)

- music (e.g., shows, concerts)

- the movie theater

- the theater

- others.

\section{PWOM definition:}

Positive feedback, approval, praise for a service.

- Use WhatsApp to send audio responses as soon as you receive PWOM about leisure services.

- Only one example of PWOM you have received regarding leisure services is enough!

- It is important that you try to record your experiences as realistically as possible. Take the time you deem necessary to record your responses.

- Only submit answers to the questions, identifying the question number.

Upon receiving PWOM regarding leisure services, please promptly send your audio responses to the researcher via WhatsApp regarding the following questions:

1. Name, nationality, and age of respondent?

2. What is your level of relationship with the sender of the recommendation?

3. After receiving the recommendation, do you intend to consume the service in question?

4. Services are usually difficult to evaluate before purchasing. Did the PWOM you received influence your evaluation of the service in question? How?

5. In general, did you feel that your choice process involved a lower risk since the service was previously recommended?

6. During the process of choosing or purchasing a service there is functional risk, for instance the risk of the service not meeting the needs. Did the recommendation reduce this risk in any way?

7. When choosing a service there is financial risk, for instance the risk of financial loss. Financial loss is related to the amount spent on a poor purchase or the availability of products offering a better price/quality ratio. Did the PWOM reduce this risk of wasting money in any way? 
8. When choosing a service there is social risk, which is the risk of the negative consequences of a poor choice in relation to your social environment. For instance, buying a particular brand or service may not be accepted by your friends and acquaintances, and bad choices may call into question your ability to make successful choices. Did the recommendation on the service somehow reduce this risk?

9. Did the PWOM about the service rationally aid your decision making? How would you explain this?

10. Did the PWOM emotionally aid your decision making somehow? How would you explain this?

11. After receiving the recommendation, did you feel that it reduced some discomfort in the decision making? How?

12. Did the recommendation generate any positive or pleasant emotion in you that influenced your decision making?

13. Did the recommendation contain detailed information about the service? Did these details assist you somehow in making the decision to choose or purchase the service? How?

14. Did the recommendation contain vibrant or impactful information that aroused your attention? Did this influence your judgment about the service in any way? How?

15. Did the information in the recommendation you received have any influence on your perception of the quality of the service? How?

16. Did the information in the recommendation have any influence on your perception of the reputation of the company providing the service? Describe.

17. Have you ever received any other recommendation from this person before? Was this recommendation valid and did it help you? Could you say that you trust this person and their recommendations?

18. Would you say that the fact that the recommendation came specifically from this person emotionally aided your decision in some way? How?

19. Upon receiving a recommendation, you have somehow interacted socially with another person. Did the fact that you did not have to decide alone, but by means of social influence, somehow aid your decision making? Describe. 


\section{Appendix D - Respondents Profile of Interviews and Audio Diaries}

Table 2

\section{Respondents profile of interviews}

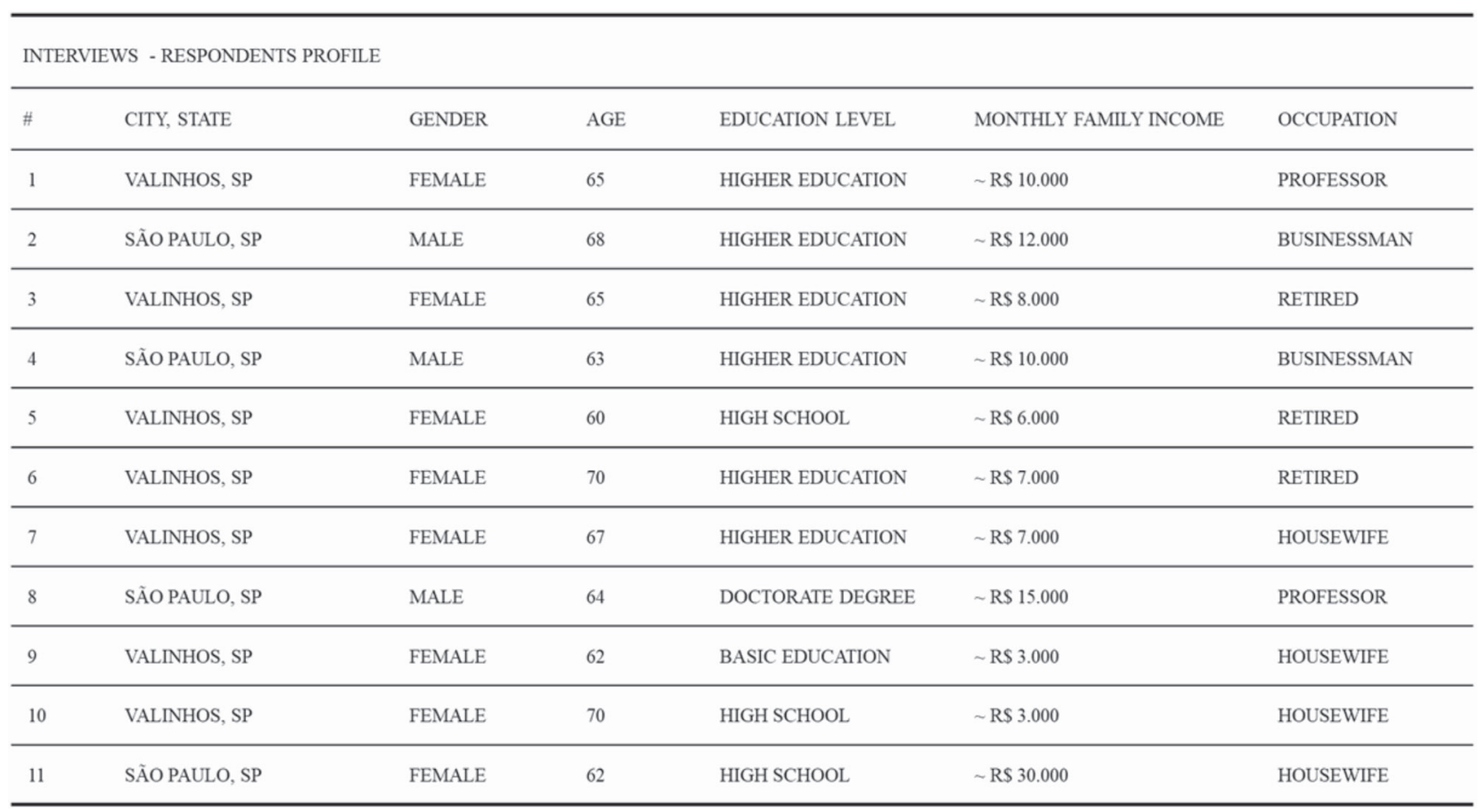

Table 3

\section{Respondents profile of audio diaries}

\begin{tabular}{|c|c|c|c|c|c|c|}
\hline \multicolumn{7}{|c|}{ AUDIO DIARIES - RESPONDENTS PROFILE } \\
\hline \# & CITY, STATE & GENDER & AGE & EDUCATION LEVEL & MONTHLY FAMILY INCOME & OCCUPATION \\
\hline 1 & VALINHOS, SP & FEMALE & 69 & HIGHER EDUCATION & $\sim \operatorname{RS} 6.000$ & RETIRED \\
\hline 2 & VALINHOS, SP & FEMALE & 65 & HIGH SCHOOL & $\sim \operatorname{R} \$ 3.000$ & RETIRED \\
\hline 3 & VALINHOS, SP & MALE & 68 & HIGH SCHOOL & $\sim \operatorname{R} \$ 7.000$ & UNIONIST \\
\hline 4 & VALINHOS, SP & MALE & 69 & HIGHER EDUCATION & $\sim \operatorname{RS} 6.000$ & RETIRED \\
\hline 5 & VALINHOS, SP & FEMALE & 61 & HIGHER EDUCATION & $\sim \mathrm{R} \$ 12.000$ & HOUSEWIFE \\
\hline 6 & VALINHOS, SP & FEMALE & 65 & HIGHER EDUCATION & $\sim \operatorname{R} \$ 6.000$ & RETIRED \\
\hline 7 & VALINHOS, SP & MALE & 64 & HIGHER EDUCATION & $\sim$ R\$ 7.000 & RETIRED \\
\hline
\end{tabular}




\section{Appendix E - PWOM Profile of Interviews and Audio Diaries}

Table 4

\section{PWOM profile of interviews}

\begin{tabular}{|c|c|c|c|c|c|c|}
\hline \multicolumn{7}{|c|}{$\begin{array}{l}\text { INTERVIEWS - PWOM PROFILE } \\
\text { Data collect performed between June - August } 2017\end{array}$} \\
\hline$\#$ & $\begin{array}{l}\text { USUAL VOLUME OF } \\
\text { PWOM RECEIVED }\end{array}$ & $\begin{array}{l}\text { WHATSAPP - NUMBER } \\
\text { OF GROUPS }\end{array}$ & $\begin{array}{l}\text { LEISURE SERVICE PWOM } \\
\text { RECEIVED }\end{array}$ & $\begin{array}{l}\text { DID YOU CONSUME THE } \\
\text { RECOMMENDED SERVICE? }\end{array}$ & $\begin{array}{l}\text { WHEN DID YOU RECEIVE } \\
\text { THE PWOM? }\end{array}$ & PWOM SENDER \\
\hline 1 & FEW & 5 & RESTAURANT & YES & $\sim 3$ YEARS AGO & FRIEND \\
\hline 2 & FEW & 5 & CRUISE & YES & DO NOT REMEMBER & COUSIN \\
\hline 3 & FEW & 4 & RESTAURANT & YES & $\sim 1,5$ YEARS AGO & COUSIN \\
\hline 4 & FEW & 4 & RESTAURANT & NO (TIME RESTRICTIONS) & DO NOT REMEMBER & FRIEND \\
\hline 5 & REASONABLE & 2 & BAR & YES & 10 YEARS AGO & FRIEND \\
\hline 6 & MANY & 7 & DANCE CLUB & YES & $\sim 3$ YEARS AGO & FRIEND \\
\hline 7 & MANY & 12 & TRAVEL AGENCY- TRIP & NO (FINANCIAL ISSUES) & $\sim 2$ YEARS AGO & FRIEND \\
\hline 8 & REASONABLE & 8 & THEATER - PLAY & YES & 2 MONTHS AGO & BROTHER \\
\hline 9 & FEW & 2 & DANCE CLUB & YES & $\sim 7$ YEARS AGO & FRIEND \\
\hline 10 & FEW & 4 & TRAVEL AGENCY - TRIP & YES & $\sim 2$ YEARS AGO & COUSIN \\
\hline 11 & REASONABLE & 15 & RESTAURANT & YES & DO NOT REMEMBER & FRIEND \\
\hline
\end{tabular}

Table 5

\section{PWOM profile of audio diaries}

\begin{tabular}{|c|c|c|c|c|c|}
\hline \multicolumn{6}{|c|}{$\begin{array}{l}\text { AUDIO DIARIES - PWOM PROFILE } \\
\text { Data collect performed between June - August } 2017\end{array}$} \\
\hline$\#$ & $\begin{array}{l}\text { USUAL VOLUME OF } \\
\text { PWOM RECEIVED }\end{array}$ & $\begin{array}{l}\text { WHATSAPP - NUMBER OF } \\
\text { GROUPS }\end{array}$ & $\begin{array}{l}\text { LEISURE SERVICE PWOM } \\
\text { RECEIVED }\end{array}$ & $\begin{array}{l}\text { DO YOU INTEND TO CONSUME THE } \\
\text { RECOMMENDED SERVICE? }\end{array}$ & PWOM SENDER \\
\hline 1 & FEW & 6 & RESTAURANT & YES & FRIEND \\
\hline 2 & REASONABLE & 7 & TRAVEL AGENCY - TRIP & YES & DAUGHTER \\
\hline 3 & FEW & 5 & DANCE CLUB & YES & FRIEND \\
\hline 4 & FEW & 4 & TRAVEL AGENCY- TRIP & YES & FRIEND \\
\hline 5 & REASONABLE & 7 & BAR & YES & DAUGHTER \\
\hline 6 & FEW & 3 & RESORT & YES & DAUGHTER IN LAW \\
\hline 7 & FEW & 2 & GYM ACADEMY & YES & FRIEND \\
\hline
\end{tabular}




\section{Authors:}

1. Juan Carlos Eiras Fontenla, visiting professor, Unicamp, Campinas, Brazil.

E-mail: juan_fontenla@hotmail.com

\section{ORCID}

(iD 0000-0001-6106-0136

2. Luciana Florêncio de Almeida, professor, ESPM-SP, Sao Paulo, Brazil.

E-mail:1florencio@espm.br

ORCID

(iD) 0000-0003-2602-3844

\section{Contribution of each author}

\section{Contribution}

1. Definition of research problem

2. Development of hypotheses or research questions (empirical studies)

3. Development of theoretical propositions (theoretical work)

4. Theoretical foundation / Literature review

5. Definition of methodological procedures

6. Data collection

7. Statistical analysis

8. Analysis and interpretation of data

9. Critical revision of the manuscript

10. Manuscript writing

11. Other (please specify which)
Juan Carlos Luciana de Fontenla Almeida

$\sqrt{ }$

$\sqrt{ }$

$\sqrt{ }$

$\sqrt{ }$

$\sqrt{ }$

$\sqrt{ }$

$\begin{array}{ll}\sqrt{ } & \sqrt{ } \\ \sqrt{ } & \sqrt{ } \\ \sqrt{ } & \sqrt{ }\end{array}$

